\title{
BENTUK TES OBJEKTIF DAN KECEMASAN PADA PEMBELAJARAN MEMBACA HURUF HIRAGANA BAHASA JEPANG
}

\author{
Kartika Sakti Oktaviani \\ Universitas Negeri Jakarta \\ Yuliatri Sastrawijaya \\ FT Universitas Negeri Jakarta
}

\begin{abstract}
This research aims to see the effect of objective tests and Japanese language anxiety toward the hiragana reading achievement in Japanese language. The form of the test includes multiple choice form and true false form of objective tests. Japanese language anxiety includes low and high anxiety. The method of research is an experimental method. While the design of research uses treatment by level $2 \times 2$. The hypothesis of research were tested by using two-way analysis of variance (ANAVA). The result of research concluded that: (I) The hiragana reading achievement in Japanese language of students who were given multiple choice form of the formative tests is higher than achievement of students reading hiragana Japanese language students who were given a true false test, (2) There is an influence of objective test form and Japanese language anxiety towards the achievement of hiragana reading in Japanese language, (3) For group of students with low Japanese language anxiety, the achievement of the group of students who were given multiple choice of objective tests is higher than the achievement of reading hiragana Japanese language students group who were given a true false of objective tests, and (4) For group of students with high Japanese language anxiety, the achievement of the group of students who were given multiple choice of objective tests is lower than the achievement of hiragana reading in Japanese language of students group given a true false of objective tests.
\end{abstract}

\section{Keywords}

Objective test, Japanese language anxiety, achievement of reading hiragana, Japanese Language

\begin{abstract}
ABSTRAK
Penelitian ini bertujuan untuk melihat pengaruh bentuk tes objektif dan kecemasan berbahasa Jepang terhadap hasil belajar membaca huruf hiragana Bahasa Jepang. Bentuk tes mencakup bentuk tes objektif pilihan ganda dan bentuk tes objektif betul salah. Kecemasan berbahasa Jepang mencakup kecemasan berbahasa Jepang rendah dan kecemasan berbahasa Jepang tinggi. Metode yang digunakan adalah treatment by level $2 \times 2$. Hipotesis penelitian diuji dengan menggunakan analisis varian (ANAVA) dua jalan. Hasil penelitian menyimpulkan bahwa: (I) hasil belajar membaca huruf hiragana Bahasa Jepang kelompok siswa yang diberi bentuk tes objektif pilihan ganda lebih tinggi dari hasil belajar membaca huruf hiragana Bahasa Jepang kelompok siswa yang diberi bentuk tes objektif betul salah, (2) terdapat pengaruh interaksi yang signifikan antara bentuk tes objektif dan kecemasan berbahasa Jepang terhadap hasil belajar membaca huruf hiragana Bahasa Jepang, (3) khusus kelompok siswa yang memiliki kecemasan berbahasa Jepang rendah, hasil belajar membaca huruf hiragana Bahasa Jepang kelompok siswa yang diberi bentuk tes objektif pilihan ganda lebih tinggi dari hasil belajar membaca huruf hiragana Bahasa Jepang kelompok siswa yang diberi bentuk tes objektif betul salah, (4) khusus kelompok siswa yang memiliki kecemasan berbahasa Jepang tinggi, hasil belajar membaca huruf hiragana Bahasa Jepang kelompok siswa yang diberi tes objektif pilihan ganda lebih rendah dari membaca huruf hiragana bahasa Jepang kelompok siswa yang diberi bentuk tes objektif betul salah
\end{abstract}

Kata Kunci

Tes Objektif, Kecemasan Berbahasa Jepang, Hasil Belajar, Membaca, Bahasa Jepang

\author{
Alamat Korespondensi \\ e-mail: \\ kartika.sakti0I@gmail.com
}




\section{Pendahuluan}

Bahasa Jepang merupakan salah satu bahasa asing yang banyak dipelajari di Indonesia. Berdasarkan survei yang dilakukan setiap tiga tahun sekali oleh The Japan Foundation, data sementara menunjukkan ada 872.406 pelajar bahasa Jepang di Indonesia pada tahun 20I2, jumlah ini meningkat 21,8 \% dibandingkan pada tahun 2009 yang hanya sebesar 716.353 orang.

Sebagai bahasa asing, bahasa Jepang juga memiliki karakteristiknya sendiri yang tentu saja membedakan antara bahasa Jepang dengan bahasa asing lainnya. Adapun karakteristik tersebut menurut Kindaiichi dalam Renariah (2002) diklasifikasikan ke dalam 5 kelompok besar, yaitu: hatsuon (ucapan), moji (huruf), goi (kosa kata), bunpou (tata bahasa), dan hyogen (ekspresi) (Kindaichi dalam Renariah, 2002).

Karakteristik yang paling menonjol dalam bahasa Jepang adalah hurufnya. Pada bahasa Jepang terdapat tiga jenis huruf, yaitu: kanji, huruf hiragana, dan huruf katakana. Dalam mempelajari bahasa Jepang, huruf hiragana merupakan huruf yang sangat penting dan tidak dapat diabaikan dalam setiap proses pembelajaran tersebut. Pada umumnya, para pembelajar pemula bahasa Jepang akan kesulitan dalam mengenali dan mempelajari huruf hiragana ini walaupun jumlahnya tidak sebanyak huruf kanji. Kesulitan yang dialami para pembelajar biasanya berupa kesulitan membaca atau mengucapkan huruf, kesulitan menuliskan huruf dengan urutan yang benar, kesulitan mengingat bentuk huruf, dan membedakan bentuk huruf yang mirip.

Keterampilan dalam berbahasa mempunyai empat komponen, yaitu: (a) keterampilan menyimak (listening skills), (b) keterampilan berbicara (speaking skills), (c) keterampilan membaca (reading skills), dan (d) keterampilan menulis (writing skills) (Tarigan, 2006). Melihat pada karakteristik bahasa Jepang yang paling menonjol, yaitu: moji (huruf), maka membaca menjadi salah satu keterampilan yang wajib dikuasai oleh siswa dalam pembelajaran bahasa Jepang. Membaca dalam bahasa Jepang juga bukan berarti hanya mengetahui huruf apa saja yang tercantum di dalam kata, frase maupun kalimat yang disajikan dalam huruf hiragana. Membaca juga berarti memetik serta memahami arti atau makna yang terkandung di dalam bahan tertulis. Untuk memudahkan siswa dalam menghafal, mengingat serta menerapkan penggunaan kosakata dan pola kalimat yang diberikan, guru selalu mengadakan evaluasi di akhir pembelajaran. Umumnya bentuk evaluasi yang diberikan berupa tes subjektif di mana siswa diminta menuliskan ulang terjemahan suatu kalimat, membuat kalimat dengan menggunakan kosakata yang disediakan, dan sebagainya. Evaluasi yang diberikan oleh guru umumnya menggunakan huruf hiragana dalam pengerjaannya. Dalam hal ini, siswa dituntut untuk menggunakan dua keterampilan berbahasa sekaligus, yaitu: keterampilan membaca dan menulis. Hal ini diharapkan siswa dapat menguasai kedua keterampilan tersebut secara bersamaan.

Akan tetapi pada kenyataannya, siswa kesulitan untuk menerapkan dua keterampilan tersebut bersamaan. Siswa yang baru satu semester mempelajari huruf hiragana, jangankan untuk menuliskan huruf hiragana dalam satu kalimat sederhana, untuk membacanya saja masih kesulitan. Jumlah huruf hiragana dan perubahannya yang banyak dirasa akan menyulitkan siswa untuk mengingatnya. Karena itulah terkadang guru menyajikan soal dalam bentuk romaji (alphabet) demi memudahkan siswa dalam membacanya. Hal ini berakibat pada kurangnya kemampuan siswa untuk membaca huruf hiragana pada saat duduk di tingkat selanjutnya. Padahal di tingkat selanjutnya siswa masih harus mempelajari huruf katakana serta kanji sederhana.

Salah satu cara yang dapat dilakukan oleh guru untuk mengetahui kemampuan membaca siswa adalah dengan menyelenggarakan evaluasi menggunakan bentuk tes objektif. Tes objektif sendiri digolongkan menjadi lima golongan, yaitu: bentuk betul salah (true false test), bentuk menjodohkan (matching test), bentuk melengkapi (completion test), bentuk isian (fill in test), dan bentuk pilihan ganda (multiple choice item test) (Anas Sudjono, 1996). Adapun sejumlah teknik pengukuran kemampuan membaca yang sering digunakan antara lain adalah dengan menggunakan bentuk betul salah, melengkapi kalimat, pilihan ganda, pembuatan ringkasan atau rangkuman, cloze test, C-test, dan lain-lain (Anderson, 1991). Sementara berdasarkan pada pendapat Kitao (1996), ragam tes objektif yang dapat dipakai 
sebagai tes membaca untuk siswa level menengah dan tinggi adalah bentuk betul salah (true-false), pilihan ganda (multiple choice), dan isian singkat.

Bentuk tes pilihan ganda dapat digunakan untuk mengukur kemampuan ingatan, pemahaman, dan penerapan yang lebih kompleks (Groundlund, 1982). Tes pilihan ganda ini juga dapat digunakan untuk mengukur kemampuan siswa yang lebih tinggi dan dapat disekor secara objektif. Tes pilihan ganda merupakan tes yang terdiri dari sejumlah butir soal yang menugasi siswa untuk memilih jawaban dari daftar pilihan yang disediakan. Menurut Widiyoko, tes pilihan ganda (multiple choice) merupakan tes di mana setiap butir soalnya memiliki jumlah alternatif jawaban lebih dari satu, pada umumnya jumlah alternatif jawaban berkisar antara 2 (dua) sampai 5 (lima) (Widoyoko, 20I4). Format tes pilihan ganda (multiple choice) menawarkan efektivitas, objektivitas, kesederhanaan, dan kemudahan dalam penggunaan untuk menilai pengetahuan siswa, tetapi permasalahannya adalah terlalu banyak sumber yang dapat menyebabkan kesalahan interpretasi Sementara itu, tes betul salah "baik untuk anak muda dan/atau siswa yang merupakan pembaca yang buruk", karena tes betul salah umumnya membutuhkan beberapa kata yang saling berkaitan, kata-kata tersebut "berguna dalam situasi khusus", seperti pengujian pada anak tingkat pertama, dan pembaca yang buruk. Pada tipe tes betul salah, pilihan atau optionnya hanya terdapat dua jenis, yaitu: B (betul) dan S (salah). Dalam bahasa Inggris option tersebut dilambangkan dengan $T$ (true) dan $F$ (false). Sementara dalam bahasa Jepang yang kemudian diadopsi ke dalam pembelajaran bahasa Jepang, lambang yang digunakan untuk dua option dalam tipe tes ini adalah $O$ (maru) untuk melambangkan pernyataan betul dan $\mathrm{X}$ (batsu) untuk melambangkan pernyataan salah.

Evaluasi bentuk tes objektif ini dalam keseharian proses pembelajaran bahasa Jepang masih amat jarang dilakukan. Padahal pada tes bentuk objektif ini, siswa dituntut untuk membaca secara menyeluruh. Membaca soal yang disajikan dalam huruf hiragana, memahami kosakata serta kalimatnya, serta menentukan jawaban yang sesuai dengan isi pertanyaan atau pernyataan yang disajikan. Karena itulah, dengan tes objektif diharapkan siswa dapat meningkatkan kemampuannya dalam membaca huruf hiragana karena membaca huruf yang sama sekali asing memang dibutuhkan proses latihan secara berkesinambungan.

Dalam proses mempelajari bahasa asing, khususnya dalam mempelajari hurufnya yang sama sekali asing. Ada faktor lain yang mempengaruhi siswa, yaitu: kecemasan sehingga dapat mempengaruhi hasil belajarnya. Kecemasan dapat membuat seseorang menjadi stres sehingga pada saat proses evaluasi (tes) dapat menurunkan tingkat rasa percaya diri, menimbulkan takut gagal dalam mengerjakan tugas, serta menimbulkan sikap negatif terhadap proses pembelajarannya (Puspita, 20I I).

Sementara kecemasan dalam bahasa Jepang merupakan perasaan gelisah, khawatir, gugup, dan ketakutan yang dialami oleh non-penutur asli ketika belajar atau menggunakan bahasa Jepang. Ada banyak faktor yang dapat mempengaruhi tingkat kecemasan. Sebagai contoh, tingkat instruksional siswa, instruktur/guru, jenis kelamin, usia, bahasa asli, penggunaan bahasa asing, lamanya waktu mempelajari bahasa asing, nilai akhir, pengalaman sebelumnya, interaksi instruktur/guru-siswa, prosedur kelas, dan sebagainya.

Bahasa Jepang juga termasuk ke dalam rumpun bahasa asing, sehingga siswa yang merasa cemas selama pelajaran bahasa Jepang akan cenderung diam selama kegiatan pembelajaran, kurang percaya diri, kurang mampu mengidentifikasi dan mengedit kesalahan bahasa, serta siswa cenderung menggunakan strategi menghindar seperti melewatkan kelas.

Tujuan dari penelitian ini agar dapat memberikan gambaran bagi guru bahasa Jepang di tingkat menengah tentang efektifitas bentuk tes objektif bentuk pilihan ganda (multiple choice) dan betul salah (true false), sehingga dapat memberikan informasi kepada pengambilan keputusan, serta dapat dijadikan bahan pertimbangan dalam upaya meningkatkan hasil belajar membaca huruf hiragana bahasa Jepang pada siswa SMA.

Selain itu, diharapkan penelitian ini dapat menjadi bahan masukan guna penyempurnaan pembelajaran bahasa asing aspek membaca, memperjelas pemahaman variabel penelitian guna memperlancar proses pembelajaran, serta 
memacu mutu kualitas hasil belajar bahasa Jepang, dan memberikan siswa kemampuan tambahan dalam berbahasa asing.

\section{Metode Penelitian}

Penelitian ini menggunakan metode eksperimen dengan desain treatment by level (2x2). Variabel perlakuan dalam penelitian ini adalah metode penskoran tes pilihan ganda, sedangkan variabel atribut adalah kecemasan berbahasa Jepang yang terdiri dari dua level, yaitu: rendah dan tinggi. Variabel terikat pada penelitian ini adalah hasil belajar membaca huruf hiragana Bahasa Jepang.

Populasi yang digunakan dalam penelitian ini adalah 307 siswa kelas X SMAN I3 Kota Bekasi. Teknik pengambilan sampel dilakukan dengan menggunakan teknik sampling acak sederhana (simple random sampling), yakni cara pengambilan sample secara sederhana dari anggota populasi dilakukan secara acak tanpa memperhatikan strata (tingkatan) dalam anggota populasi tersebut. Adapun besar anggota sampel dalam penelitian ini sejumlah 40 siswa.

Perlakuan yang diterapkan dalam penelitian ini adalah bentuk soal tes objektif yang diberikan dalam bentuk ulangan harian dan umpan baliknya. Kepada kelompok eksperimen diberikan perlakuan dengan bentuk tes objektif pilihan ganda (multiple choice) dan pada kelompok kontrol diberikan perlakuan dengan bentuk tes objektif betul salah (true false). Adapun frekuensi tes objektif diberikan kepada siswa sebanyak sembilan kali secara berkesinambungan terus menerus pada setiap akhir pertemuan.

Dalam penelitian ini terdapat dua macam data yang dikumpulkan melalui instrumen penelitian, yaitu: data hasil belajar membaca huruf hiragana Bahasa Jepang dan data kecemasan berbahasa Jepang. Instrumen tes hasil belajar membaca huruf hiragana bahasa Jepang digunakan untuk mengukur hasil belajar siswa setelah mendapatkan perlakuan. Instrumen tes hasil belajar membaca huruf hiragana Bahasa Jepang dikembangkan oleh peneliti, terdiri dari 10 butir soal uraian singkat materi pelajaran bahasa Jepang SMA kelas $X$ semester II tahun pelajaran 2015/2016 mengenai pokok bahasan Gakkou (Sekolah), dengan koefisien reliabilitas konsistensi internal sebesar 0,826. Instrumen kecemasan berbahasa Jepang, peneliti mengadaptasi dari Foreign Language Classroom Anxiety Scale yang dikembangkan oleh Horwitz, terdiri dari 32 butir dengan koefisien reliabilitas konsistensi internal sebesar 0,908.

Normalitas data diuji dengan menggunakan uji Lilliefors, sedangkan homogenitas varians diuji dengan menggunakan uji Fisher dan uji Bartlett. Hipotesis penelitian diuji dengan menggunakan teknik analisis varians (ANAVA) dua jalur dilanjutkan dengan uji pengaruh sederhana (simple effect) menggunakan uji t-Dunnet.

\section{Hasil Penelitian dan Pembahasan}

Hasil pengujian hipotesis penelitian menggunakan teknik analisis varians (ANAVA) dapat dilihat pada Tabel I.

Tabel I. Hasil Perhitungan Analisis Varian (ANAVA) Dua Jalan pada $\alpha=0.05$ dan $\alpha=0.01$

\begin{tabular}{ccccccc}
\hline $\begin{array}{c}\text { Sumber } \\
\text { Varians }\end{array}$ & JK & Db & \multirow{2}{*}{ RJK } & Fo & \multicolumn{2}{c}{$\mathbf{F}_{\text {Tabel }}$} \\
\hline Antar A & 378.3 & $\mathrm{I}$ & 378.3 & 9.52 & $4.1 \mathrm{05}$ & $\mathbf{\alpha = 0 . 0 1}$ \\
Interaksi AB & 1946.0 & $\mathrm{I}$ & 1946.0 & 48.97 & & \\
Dalam & 1430.5 & 36 & 39.736 & - & & \\
Total & 3810 & 39 & - & - & & \\
\hline
\end{tabular}

Sebagai konsekuensi terjadinya interaksi, maka perlu dilakukan uji pengaruh sederhana (simple effect) untuk menguji perbedaan hasil belajar membaca huruf hiragana bahasa Jepang antara kelompok siswa yang memiliki kecemasan berbahasa Jepang rendah yang diberikan tes objektif pilihan ganda dengan kelompok siswa yang diberikan tes objektif betul salah, dan perbedaan hasil belajar membaca huruf hiragana bahasa Jepang antara kelompok siswa yang memiliki kecemasan berbahasa Jepang tinggi yang diberikan tes objektif pilihan ganda dengan kelompok siswa yang diberikan tes objektif betul salah. Hasil uji t-Dunnet dapat dirangkum dalam Tabel 2. 
Tabel 2. Rangkuman Hasil Uji t-Dunnet

\begin{tabular}{cccc}
\hline $\begin{array}{c}\text { Perbandingan } \\
\text { Kelompok }\end{array}$ & \multicolumn{2}{c}{ Uji t-Dunnet } & \multirow{2}{*}{ Simpulan } \\
\cline { 2 - 3 } $\mathrm{A}_{1} \mathrm{~B}_{1}-\mathrm{A}_{2} \mathrm{~B}_{1}$ & 6,56 & $\mathbf{t}_{\text {tabel }(\mathbf{0}, 05)}$ & \\
$\mathrm{A}_{1} \mathrm{~B}_{2}-\mathrm{A}_{2} \mathrm{~B}_{2}$ & 3.06 & $\mathrm{I}, 73$ & Tolak $\mathrm{H}_{0}$ \\
& & $\mathrm{I}, 73$ & Tolak $\mathrm{H}_{0}$ \\
\hline
\end{tabular}

Pertama, Berdasarkan hasil analisis varians (ANAVA) pada Tabel $\mathrm{I}$ di atas, diperoleh $\mathrm{F}_{\text {hitung }}$ $=9.52>\mathrm{F}_{\text {tabel }}=4.1 \mathrm{I}$ pada $\alpha=0.05$, maka $\mathrm{H}_{0}$ ditolak. Artinya dapat dikatakan bahwa terdapat perbedaan hasil belajar membaca huruf hiragana bahasa Jepang kelompok siswa yang diberi tes objektif pilihan ganda $\left(A_{1}\right)$ dengan kelompok siswa yang diberi tes objektif betul salah $\left(A_{2}\right)$. Analisis varian ini diperkuat dengan melakukan uji perbedaan rata-rata hasil belajar membaca huruf hiragana bahasa Jepang dari kedua kelompok tersebut.

Adapun perbedaan nilai rata-rata hasil belajar membaca huruf huruf hiragana bahasa Jepang kelompok siswa yang diberi bentuk tes pilihan ganda $\left(A_{1}\right)$ sebesar 82.25 , dan nilai rata-rata hasil belajar membaca huruf hiragana kelompok siswa yang diberi tes objektif bentuk betul salah $\left(A_{2}\right)$ sebesar 76.40. Dengan demikian dapat disimpulkan bahwa hasil belajar membaca huruf hiragana Bahasa Jepang kelompok siswa yang diberi tes objektif pilihan ganda $\left(A_{1}\right)$ lebih tinggi dari hasil belajar membaca huruf hiragana bahasa Jepang kelompok siswa yang diberi tes objektif betul salah $\left(A_{2}\right)$.

Kedua, berdasarkan hasil analisis varians (ANAVA) pada tabel $\mathrm{I}$ di atas diperoleh $\mathrm{F}_{\text {hitung }}=$ $48.97>\mathrm{F}_{\text {tabel }}=4.1 \mathrm{I}$ pada $\alpha=0.05$, maka $\mathrm{H}_{0}$ ditolak. Dengan demikian dapat dikatakan bahwa terdapat pengaruh interaksi tes objektif dan kecemasan berbahasa Jepang terhadap hasil belajar membaca huruf hiragana bahasa Jepang.

Ketiga, berdasarkan hasil analisis Uji t-Dunnet yang hasilnya menunjukkan bahwa nilai $t_{\text {hitung }} 6.56$ lebih besar dari $t_{\text {tabel }}$ I.73. Ini mempunyai arti bahwa khusus kelompok siswa yang memiliki kecemasan berbahasa Jepang rendah, rata-rata hasil belajar membaca huruf hiragana bahasa Jepang kelompok siswa yang diberi tes objektif bentuk pilihan ganda lebih tinggi dari rata-rata hasil belajar membaca huruf hiragana bahasa Jepang kelompok siswa yang diberi tes objektif bentuk betul salah.
Dari penjelasan di atas dapat disimpulkan bahwa khusus kelompok siswa yang memiliki kecemasan berbahasa Jepang rendah, hasil belajar membaca huruf hiragana bahasa Jepang kelompok siswa yang diberi tes objektif bentuk pilihan ganda lebih tinggi dari hasil belajar membaca huruf hiragana bahasa Jepang kelompok siswa yang diberi tes objektif bentuk betul salah. Kenyataan tersebut dapat dijelaskan bahwa di dalam bentuk tes objektif pilihan ganda terdapat aspek kemampuan mengevaluasi diri. Kemampuan mengevaluasi diri sendiri sangat terkait dengan kesiapan menerima umpan balik. Kesediaan menerima umpan balik itu sendiri merupakan salah satu unsur yang memacu keinginan siswa untuk lebih memahami penggunaan huruf hiragana dalam bentuk kata maupun kalimat.

Kelompok siswa yang memiliki kecemasan berbahasa Jepang rendah akan lebih percaya diri dan yakin dalam mengerjakan tugas bahasa Jepang yang disajikan dalam huruf hiragana. Mereka cenderung akan lebih percaya diri dalam membaca soal-soal yang disajikan dalam huruf hiragana, serta mencari padanan kata maupun kalimat yang disajikan dalam huruf hiragana pula. $\mathrm{Hal}$ ini sesuai dengan bentuk tes objektif pilihan ganda, di mana soal yang disajikan dalam kondisi rumpang dan siswa diminta memilah, mengidentifikasi hingga memahami pilihan yang tepat untuk melengkapi kalimat rumpang tersebut. Karena itu, tes objektif bentuk pilihan ganda sesuai dengan mereka yang memiliki kecemasan berbahasa asing rendah.

Sebaliknya dengan tes objektif bentuk betul salah, kelompok siswa yang memiliki kecemasan berbahasa Jepang rendah akan menganggap mudah soal-soal yang disajikan. Hal ini disebabkan soal hanya disajikan dalam satu kalimat utuh yang menuntut siswa untuk membaca serta memahaminya saja. Siswa akan merasa bosan dan jenuh ketika diberikan tugas bahasa Jepang untuk dikerjakan. Mereka tidak merasa cemas, gugup 
maupun gelisah saat menghadapi soal dalam bentuk tes objektif betul salah ini, sehingga dapat mengakibatkan soal hanya dibaca secara sepintas saja tanpa dipahami arti maupun maksudnya. Karena itu kelompok siswa yang diberi bentuk tes objektif bentuk betul salah dan memiliki kecemasan berbahasa Jepang rendah tidak dapat mencapai nilai optimal pada mata pelajaran bahasa Jepang.

Keempat, berdasarkan analisis uji lanjut tDunnet pada kelompok siswa yang memiliki kecemasan berbahasa Jepang tinggi $\left(B_{2}\right)$ diperoleh $F_{\text {hitung }} 9.34$ lebih besar dari $F_{\text {tabel }}$ 4.20. Ini menunjukkan bahwa khusus kelompok siswa yang memiliki kecemasan berbahasa Jepang tinggi, terdapat perbedaan hasil belajar membaca huruf hiragana bahasa Jepang kelompok siswa yang diberi tes objektif bentuk pilihan ganda dengan hasil belajar membaca huruf hiragana bahasa Jepang kelompok siswa yang diberi tes objektif bentuk betul salah. Perbedaan ini ditunjukkan dengan nilai rata-rata hasil belajar membaca huruf hiragana bahasa Jepang kelompok siswa yang diberikan tes objektif bentuk pilihan ganda sebesar 82.25 dan nilai rata-rata hasil belajar membaca huruf hiragana Bahasa Jepang kelompok siswa yang diberi tes objektif bentuk betul salah sebesar 76.40. Ini mempunyai arti bahwa khusus kelompok siswa yang memiliki kecemasan berbahasa Jepang tinggi, terdapat perbedaan antara hasil belajar membaca huruf hiragana bahasa Jepang kelompok siswa yang diberi tes objektif bentuk pilihan ganda dengan hasil belajar membaca huruf hiragana bahasa Jepang kelompok siswa yang diberi tes objektif bentuk betul salah. Perbedaan ini dilanjutkan dengan Uji t-Dunnet yang hasilnya menunjukkan bahwa nilai $t_{\text {hitung }} 6.56$ lebih besar dari $t_{\text {tabel }}$ I.73. Ini mempunyai arti bahwa khusus kelompok siswa yang memiliki kecemasan berbahasa Jepang tinggi, rata-rata hasil belajar membaca huruf hiragana bahasa Jepang kelompok siswa yang diberi tes objektif bentuk pilihan ganda lebih rendah dari rata-rata hasil belajar membaca huruf hiragana bahasa Jepang kelompok siswa yang diberi tes objektif bentuk betul salah.

Berdasarkan penjelasan di atas, dapat disimpulkan bahwa khusus kelompok siswa yang memiliki kecemasan berbahasa Jepang tinggi, hasil belajar membaca huruf hiragana bahasa Jepang kelompok siswa yang diberi bentuk tes objektif pilihan ganda lebih rendah dari hasil belajar membaca huruf hiragana bahasa Jepang kelompok siswa yang diberi tes objektif bentuk betul salah. Kenyataan tersebut di atas dapat dijelaskan bahwa bentuk tes objektif pilihan ganda merupakan suatu bentuk tes yang diberikan oleh guru kepada siswa untuk menyelesaikan soal-soal bahasa Jepang yang tersaji dalam huruf hiragana. Namun untuk kelompok siswa yang memiliki kecemasan berbahasa Jepang tinggi, bentuk tes objektif pilihan ganda ini tidak efektif untuk dilaksanakan. Hal ini disebabkan siswa yang memiliki kecemasan berbahasa Jepang tinggi kesulitan untuk mengidentifikasi dan memadankan pilihan kata serta kalimat yang disajikan dalam huruf hiragana. Rasa takut dan cemas yang ada pada diri mereka, dapat mempengaruhi proses memilih jawaban yang tepat untuk melengkapi kalimat rumpang yang disajikan dalam huruf hiragana pula. Kenyataannya banyak di antara kelompok mereka yang tidak menyelesaikan soal-soal bahasa Jepang dengan benar.

Sedangkan pada kelompok siswa yang diberi bentuk tes objektif betul salah, mereka lebih menyukai keadaan yang biasa-biasa saja, di mana mereka merasa aman dan nyaman serta tidak cemas. Kelompok ini dengan tingkat kecemasan yang tinggi, merasa mampu menghadapi soal berupa kalimat utuh tanpa harus memadankan suatu kalimat rumpang dengan jawabannya.

\section{Kesimpulan}

Berdasarkan hasil pengujian hipotesis penelitian dan pembahasan hasil penelitian maka dapat ditarik beberapa kesimpulan, yaitu: (I) Hasil belajar membaca huruf hiragana Bahasa Jepang kelompok siswa yang diberi bentuk tes objektif pilihan ganda lebih tinggi dari hasil belajar membaca huruf hiragana Bahasa Jepang kelompok siswa yang diberi bentuk tes objektif betul salah. (2) Terdapat pengaruh interaksi yang signifikan antara bentuk tes objektif dan kecemasan berbahasa Jepang terhadap hasil belajar membaca huruf hiragana bahasa Jepang. (3) Khusus kelompok siswa yang memiliki kecemasan berbahasa Jepang rendah, hasil belajar membaca huruf hiragana bahasa Jepang kelompok 
siswa yang diberi bentuk tes objektif pilihan ganda lebih tinggi dari hasil belajar membaca huruf hiragana bahasa Jepang kelompok siswa yang diberi bentuk tes objektif betul salah. (4) Khusus kelompok siswa yang memiliki kecemasan berbahasa Jepang tinggi, hasil belajar membaca huruf hiragana bahasa Jepang kelompok siswa yang diberi tes objektif pilihan ganda lebih rendah dari hasil belajar membaca huruf hiragana bahasa Jepang kelompok siswa yang diberi bentuk tes objektif betul salah.

\section{Daftar Pustaka}

Anderson, Neil J., Lyle Bachman, Kyle Perkins and Andrew Cohen. (1991). "An Exploratory into The Construct Validity of a Reading Comprehension Test: Triangulation of Data Source." Language Testing, Vol 8(I).

Groundlund, Norman E. (1997). Constructing Achievement Test (Second Edition). New York: Prentice Hall, Inc., Engelwood Cliffs.

Horwitz, Elaine Kolker. (2008). Becoming a Language Teacher (A Practical Guide to Second Language Learning and Teaching). New Jersey: Pearson Education, Inc.

Horwitz, Elaine K., Michael B. Horwitz, Joann Cope. (1986). "Foreign Language Classroom Anxiety”. The Modern Language Journal, Vol 70(2).

Kitao, S. Kathleen dan Kenji Kitao, (1996). "Testing Reading". Microfiche Report, Washington DC: Distributed by ERIC Clearinghouse.
Puspita, Tita. (20II). "Pengaruh Jumlah Pilihan Jawaban Pada Bentuk Tes Pilihan Ganda dan Kecemasan Matematika Terhadap Daya Beda Butir Soal Matematika." Tesis, PPSUNJ.

Sudijono, Anas. (1996). Pengantar Evaluasi Pendidikan. Jakarta: PT. Raja Grafindo Persada.

Tarigan, Henry Guntur. (1985). Menulis Sebagai Suatu Keterampilan Berbahasa. Bandung: Angkasa.

Tarigan, Henry Guntur. (2008). Membaca Sebagai Suatu Keterampilan Berbahasa. Bandung: Angkasa.

Tasdemir, Mehmet. (2010). "A Comparison of Multiple-Choice Tests and True-False Test Used in Evaluating Student Progress." Journal of Instructional Psychology, Vol 37(3).

Widoyoko, S. Eko Putro. (20/4). Evaluasi Program Pembelajaran (Panduan Praktis Bagi Pendidik dan Calon Pendidik). Yogyakarta: Pustaka Pelajar.

Halo Jepang. "Jumlah Pelajar Bahasa Jepang di Indonesia Kedua terbesar Dunia". Halo Jepang Online http://halojepang.com/sosial pendidikan/74II-survey. 